\title{
A STUDY OF THE REPERTOIRE OF ACTIVATED T-CELL CLONES OBTAINED FROM A PATIENT WITH ANKYLOSING SPONDYLITIS
}

\author{
Komech EA, Lebedev YB, Koshenkova AV, Syrko DS, Musatkina EA, Lukyanov SA, Chudakov DM, Zvyagin IV $\bowtie$
}

Pirogov Russian National Research Medical University, Moscow, Russia

Recent studies of T-cell clonal repertoires of patients with ankylosing spondylitis (AS) have led to the discovery of AS-associated T-cell clones with a highly homologous T-cell receptor structure. The role of T-lymphocytes in the disease progression cannot be elucidated without analyzing the diversity and abundance of functionally different T-cell clones found in patient with AS. Using a state-of-the-art technique for T-cell repertoire profiling based on massively parallel sequencing, we, for the first time, studied the T-cell repertoire of activated T-cells from the peripheral blood of a patient with AS. We have demonstrated that a subpopulation of $\mathrm{CD}_{3}{ }^{+} \mathrm{HLA}-\mathrm{DR}^{+}$T-lymphocytes is highly diverse both in terms of clonal diversity and abundance of the identified clonotypes, suggesting diverse antigen specificity of the activated peripheral blood T-cells. Most of the activated T-cell clonotypes had low abundance in total population of peripheral blood T-cells. In the repertoire of activated T-cells we have found the clonotype TRBV9_CASSVGVYSTDTQYF_TRBJ2-3, previously discovered in AS and reactive arthritis, and a few other clonotypes of cytotoxic and helper T-cells that may have a role in promoting inflammation in AS patients. Presence of the AS-associated clonotypes in activated T-cell subset suggests that the T-cells might play an active role in ongoing inflammation during the disease progression. This provides rationale for further research of their antigen specificity and role in triggering or maintaining AS.

Keywords: T-cell repertoire, ankylosing spondylitis, activated T lymphocytes, Bekhterev's disease, T-cell subpopulation, clonal repertoire

Funding: this work was supported by the Ministry of Education and Science of the Russian Federation, Project ID RFMEFI60716X0158.

Acknowledgement: we are grateful to the patient who has kindly given his consent to participate in the study; to Denis Fedorenko, a hematologist and Professor of Maximov Hematology and Cell Therapy Department (Pirogov National Medical Surgical Center) for his consultations; Elena Kovalenko, a senior researcher at Shemyakin-Ovchinnikov Institute of Bioorganic Chemistry, for her assistance in conducting a flow cytometry analysis.

Correspondence should be addressed: Ivan Zvyagin

ul. Ostrovityanova, d. 1, Moscow, Russia, 117997; izvyagin@gmail.com

Received: 15.12.2017 Accepted: 25.12.2017

DOI: $10.24075 / \mathrm{brsmu} .2018 .001$

\section{ИССЛЕДОВАНИЕ КЛОНАЛЬНОГО РЕПЕРТУАРА ФРАКЦИИ АКТИВИРОВАННЫХ Т-ЛИМФОЦИТОВ У ПАЦИЕНТА С АНКИЛОЗИРУЮЩИМ СПОНДИЛИТОМ}

Е. А. Комеч, Ю. Б. Лебедев, А. В. Кошенкова, Д. С. Сырко, Е. А. Мусаткина, С. А. Лукьянов, Д. М. Чудаков, И. В. Звягин

Российский национальный исследовательский медицинский университет имени Н. И. Пирогова, Москва

Недавние исследования клонального репертуара Т-клеток при анкилозирующем спондилите (АС) позволили идентифицировать группу клонов Т-лимфоцитов с высокогомологичной структурой Т-клеточного рецептора, ассоциированных с развитием АС. Определение роли Т-лимфоцитов в развитии заболевания требует исследований клонального состава функционально различных субпопуляций Т-клеток больных АС. С использованием современной технологии реконструкции клонального репертуара Т-клеток на базе массированного параллельного секвенирования нами был впервые исследован клональный репертуар активированных Т-лимфоцитов периферической крови пациента с АС. Мы обнаружили высокое разнообразие клонального состава фракции Т-лимфоцитов, экспрессирующих маркеры активации CD38 и HLA-DR, как по численности клеток, представляющих идентифицированные клонотипы, так и по структуре Т-клеточного рецептора клонотипов, что свидетельствует о разнообразной антигенной специфичности активированных Т-лимфоцитов периферической крови пациента. Основу клонального разнообразия составили малопредставленные в общем репертуаре клонотипы Т-клеток. В составе репертуара фракции был обнаружен ранее ассоциированный с AC и реактивным артритом клонотип TRBV9_CASSVGVYSTDTQYF_TRBJ2-3, а также ряд других клонотипов субпопуляций цитотоксических и хелперных Т-клеток, вероятно, связанных с воспалительным процессом при АС. Экспрессия маркеров активации клетками ассоциированных с АС клонотипов демонстрирует активное участие таких клонов в воспалительной реакции при заболевании, определяя актуальность исследования их антигенной специфичности и роли в возникновении и/или развитии АС.

Ключевые слова: Т-клеточный репертуар, анкилозирующий спондилит, активированные Т-лимфоциты, болезнь Бехтерева, субпопуляция Т-лимфоцитов, клональный репертуар

Финансирование: работа поддержана Министерством образования и науки РФ, идентификатор проекта RFMEFI60716X0158.

Благодарности: авторы выражают признательность пациенту, принявшему участие в исследовании; врачу-гематологу, профессору кафедры гематологии и терапии им. А. А. Максимова Денису Анатольевичу Федоренко из Национального медико-хирургического центра имени Н. И. Пирогова за консультации по клиническим вопросам; старшему научному сотруднику Елене Ивановне Коваленко из Института биоорганической химии им. М. М. Шемякина и Ю. А. Овчинникова за помощь в осуществлении цитофлуорометрического анализа.

$\bowtie$ Для корреспонденции: Звягин Иван Владимирович

ул. Островитянова, д. 1, г. Москва, 117997; izvyagin@gmail.com

Статья получена: 15.12.2017 Статья принята к печати: 25.12.2017

DOI: $10.24075 /$ vrgmu.2018.001 
Ankylosing spondylitis (AS, also known as Bekhterev's disease) is a chronic rheumatic, presumably autoimmune disorder. Genome-wide association studies link the risk of AS development to certain allelic variants of genes of antigenpresenting system (HLA and ERAP1/2) and cytokine receptors involved in proinflammatory response [1]. Strong association between risk of the disease and certain alleles of $H L A-B$ and protective effect of some other HLA-B variants (HLA-B is involved in antigen presentation) have inspired a hypothesis suggesting that T-cell recognition of self-antigens in complex with HLA-B ${ }^{\star} 27$ triggers AS [2]. Recent studies of T-cell clonal repertoires in patients with $A S$ have allowed to discover a group of cytotoxic T-lymphocyte clones with a highly homologous antigen-recognizing part of T-cell receptor (TCR); these clones are specific to AS and found in patients' peripheral blood and synovial fluid obtained from the inflamed joints [3, 4]. Previously, clones of T-lymphocytes with a similar or identical TCRs were found in the synovial fluid of patients with reactive arthritis, another member of the spondylarthropathies family [5-7].

Of particular interest are functional characteristics of the T-cell clones hypothesized to trigger and/or maintain inflammation. This work was aimed to study the clonal repertoire of subpopulation of activated T-lymphocytes isolated from the peripheral blood of a patient with active ankylosing spondylitis. For T-cell repertoire profiling, we applied a state-of-the-art technology based on the next-generation sequencing (NGS) of TCR $\beta$ CDNA libraries that were prepared using molecular barcoding technique [8, 9]; molecular barcoding is essential for correction of sequencing errors and estimation of the abundance of T-cell clones in the sample. After reconstruction of the repertoire and investigation of it's structure, we searched for the published AS-associated clones among the clonotypes of the studied T-cell subset. To estimate the abundance of the clonotypes identified in activated T-cell subset and attribute them to one of the two major functional T-cell subpopulations, we profiled the repertoire of the entire T-cell population and $\mathrm{CD}^{+}$and $\mathrm{CD}^{+}{ }^{+} \mathrm{T}$-cell subsets obtained from peripheral blood of the patient.

\section{METHODS}

\section{Patient}

A 28-year old man with axial ankylosing spondylitis (Bekhterev's disease) was diagnosed 7 years before our study. The patient was $H L A-B^{\star} 27$ positive. The treatment he was receiving included nonsteroidal anti-inflammatory drugs (arcoxia), methotrexate, and TNF- $\alpha$ inhibitors (Humira) Three years before blood collection, the patient underwent high-dose immunosuppression therapy with $200 \mu \mathrm{g} / \mathrm{kg}$ cyclophosphamide+anti-thymocyte globulin followed by autologous hematopoietic cell transplantation without CD34 ${ }^{+}$ enrichment. Six months later the patient had relapse of the disease following a respiratory infection. At the time of blood collection the patient had active AS manifested as severe pain and limited mobility of joints.

\section{Isolation of PBMC and T-cell subsets}

Eight milliliters of patient's peripheral blood were collected into K3-EDTA vacutainers (BD Biosciences, USA). Mononuclear cells were isolated by standard Ficoll density gradient centrifugation (1.077 g/ $/ \mathrm{cm}^{3}$, PanEco, Russia). Two peripheral blood samples of identical volume (F1 and F2) were obtained simultaneously and later used as two independent replicates for whole T-lymphocyte repertoire profiling. Subsets of CD4+ and $\mathrm{CD}^{+}$cells were isolated from separate blood samples using Dynabeads cell isolation kit (Invitrogen, USA).

Subpopulation of the activated T-lymphocytes expressing CD38 and HLA-DR markers was isolated from peripheral blood mononuclear cells by flow cytometry (FACSVantage, BD Biosciences). At the time point 1 we isolated a subpopulation of $\mathrm{CD}^{+} \mathrm{CD} 38^{+} \mathrm{HLA}-\mathrm{DR}^{+}$lymphocytes. Two months later (time point 2) subpopulations of $\mathrm{CD}^{+} \mathrm{CD} 8{ }^{+} \mathrm{CD} 38^{+} \mathrm{HLA}-\mathrm{DR}^{+}$ and $\mathrm{CD}^{+} \mathrm{CD} 8^{-} \mathrm{CD} 38^{+} \mathrm{HLA}-\mathrm{DR}^{+}$cells were isolated from the patient's peripheral blood sample. The panel of antibodies for flow cytometry included CD3-APC (Invitrogen), CD8FITC (Invitrogen), HLA-DR-PerCP (Invitrogen) and CD38PE (IQProducts, Netherlands). Staining with antibodies was performed according to the protocols of manufacturers. The cells were lysed in $350 \mu \mathrm{l} R \mathrm{LT}$ buffer (Qiagen, Netherlands), and total RNA was then isolated for subsequent TCR repertoire profiling.

\section{Preparation of cDNA libraries}

RNA from PBMC, and $\mathrm{CD}^{+}$and $\mathrm{CD}^{+}$cell subsets, was isolated using TRlzol (Invitrogen) according to the manufacturer's protocol. RNA of T-lymphocytes obtained by flow cytometry was isolated using the RNAeasy Mini reagent kit (Qiagen) according to the manufacturer's protocol. TCR $\beta$ cDNA libraries were prepared as described in [10]. The libraries were sequenced on HiSeq 2000/2500 (Illumina, USA) in the pairedend mode with a $100 \mathrm{bp}$ read length.

\section{Sequencing data processing}

To correct sequencing errors and count unique TCR CDNA molecules in the library, we used MiGEC (a software pipeline utilizing the principle of molecular barcoding) [8, 11]. V-, Dand $\mathrm{J}$-segments and CDR3 sequence were determined using MiXCR [12], which was also employed to quantify clonotypes and form a list of the identified clonotypes for each sample. For clonal sequence assembly only TCR cDNA sequences covered by at least two reads were used (based on analysis of unique molecular identifiers $(\mathrm{UMI})$ ), the restriction allowed to eliminate the majority of sequencing errors and to reduce the artificial clonal diversity of the repertoire [13]. Further bioinformatic analysis was performed using $R$ programming language [14].

The identified clonotypes were associated with a particular T-cell phenotype based on detection of each particular clonotype (combination of CDR3 nucleotide sequences with TCR V-segment) in repertoires of the T-cell subpopulations.

\section{The use of published TCR $\beta$ CDNA sequencing data}

In this work, we also used data on TCR $\beta$ cDNA repertoire profiling peripheral blood and synovial fluid samples from $H L A-B^{\star} 27$ positive patients with AS. These data have been already published and are currently available in NCBI SRA database (SRP111372) [4]. The published sequencing data and data obtained for the present study were processed identically.

\section{RESULTS}

\section{Characteristics of the studied cell samples and technology} used for clonal repertoire profiling

For clonal T-cell repertoire analysis 50,000 cells expressing CD3, CD38 and HLA-DR were isolated using flow cytometry 
from peripheral blood sample of the patient with AS. At the time of blood sampling the patient had joint pain and limited mobility of joints and was not receiving any anti-cytokine therapy. Flow cytometry revealed that the subpopulations of CD3+HLA-DR+ and CD3+CD38+HLA-DR+ cells accounted for $2.6 \%$ and $1,5 \%$ of patient's T-lymphocytes, respectively. These results are consistent with the literature reporting similar proportions for peripheral blood lymphocytes of healthy donors of the same age [15]. In our case, increased frequency of CD3+CD38+ T-cells was observed: $39.2 \%$ for the AS patient vs. $5.85 \%$ to $24.6 \%$ in healthy donors of the same age.

At that time point, samples of cytotoxic $\left(\mathrm{CD}^{+}\right)$and helper $\left(\mathrm{CD} 8^{+}\right)$T-lymphocytes and two samples of unfractionated mononuclear cells ( $\mathrm{F} 1$ and F2) were obtained from peripheral blood of the donor.

For TCR $\beta$ clonal repertoire profiling, we applied an original technology, which includes the following features:

1) template-switch-based cDNA synthesis, that allowed us to use universal primers for TCR cDNA amplification to minimize amplification bias associated with differences in the structure of a variable V-segment (part of a mature TCR gene);

2) molecular barcoding [8], that allows to estimate the depth of T-cell repertoire analysis and abundance of the identified clonotypes [9]; during preprocessing of sequencing data, molecular barcodes are used for correction of sequencing errors that helps to reduce the artificial diversity of the clonal repertoire originating from such errors [11];

3) introduction of sample-specific barcodes on both ends of cDNA library molecules. One of the barcode is introduced during cDNA synthesis step [10] allowing to exclude crosscontamination of samples both at the stage of sample preparation and during sequencing. Low probability of crosscontamination, in turn, allows to associate of the identified clonotypes with a particular T-cell phenotype. Such association is based on the identification of a unique nucleotide sequence of a variable TCR region in repertoires of different T-cell subsets (CD4 ${ }^{+}, \mathrm{CD}^{+}, \mathrm{F} 1$ and $\left.\mathrm{F} 2, \mathrm{CD}^{+} \mathrm{CD} 38^{+} \mathrm{HLA}-\mathrm{DR}^{+}\right)$.

Sequencing of TCR $\mathrm{CDNA}$ libraries yielded a total of 20.25 million reads: 6.23 and 7.53 million reads for F1 and F2 samples, respectively; 2.78 million reads for the $\mathrm{CD}^{+}{ }^{+}$subset; 2.96 million reads for the $\mathrm{CD}^{+}$subset and 0.75 million reads for the $\mathrm{CD}^{+} \mathrm{CD} 38^{+} \mathrm{HLA}-\mathrm{DR}^{+}$cell subpopulation. For further analysis and reconstruction of a variable TCR $\beta$ region (recovery of a CDR3 nucleotide sequence and a V-segment, i.e. identification of a T-cell clonotype) we used cDNA sequences covered by at least two reads. This allowed us to further reduce the artificial diversity of the repertoire originating from erroneous clonotypes [13, 16].

The total T-cell repertoire profiling depth reached about 1.6 million unique clonotypes. For samples F1, F2, CD4 and CD8, 3.3 million TCR $\beta$ cDNA molecules were analyzed $(969,000$, $1,260,000,601,000$ and 652,000, respectively). According to the previously published efficiency of the TCR repertoire profiling technology used, the total depth of analysis was about 3.3 million T-cells $[13,16]$. Sequencing yielded 17,296 TCR $\beta$
cDNA sequences for $\mathrm{CD}^{+}{ }^{+} \mathrm{CD} 38^{+}+\mathrm{HLA}-\mathrm{DR}^{+}$cells, covered by at least two reads, while the total number of cells in this sample was 50,000. Thus, on average every TCR $\beta$ cDNA sequence corresponded to a TCR mRNA of a distinct T-cell, and the total depth of TCR repertoire analysis of the subpopulation was about 17,000 unique T-cells.

\section{Abundance of activated T-cell clonotypes in the total repertoire of T-cells}

On the first step of TCR repertoire analysis of the activated T-cell subpopulation, we studied the distribution of the identified clonotypes in the total repertoire of peripheral blood T-cells. Over $85 \%(10,212$ of 11,927) of the identified activated T-cell clonotypes were not found in repertoires of any other samples: unfractionated T-cells ( $F 1$ and F2) or cytotoxic/ helper T-cell subsets (Table 1). The probability to observe a specific clonotype in the sample is roughly proportional to the number of T-lymphocytes bearing the same TCR in the total T-cell population (i. e. to the abundance of a clonotype in the repertoire). High repertoire diversity and different abundance of T-cell clones combined with a relatively small volume of the sample can explain the substantial part of unique T-cell clonotypes between two independent blood samples obtained at the same time point.

Current estimate of the potential diversity of TCR $\beta$ repertoire is about $10^{8}$ variants [17]; in our study the abundance of clonotypes in the total T-cell population varied between $1.5 \%$ to $8.6 \times 10^{-6} \%$ T cells. To determine whether the observed high number of unique clonotypes was specific to the $\mathrm{CD}^{+}{ }^{+} \mathrm{CD} 38^{+}+\mathrm{HLA}-\mathrm{DR}^{+}$subset, we estimated the repertoire overlap between total T-cell sample F1 and T-cell subsets expressing CD4 and CD8 surface markers with the sample F2. To obtain comparable repertoire analysis depth with fraction of activated T-lymphocytes, the repertoires of F1, CD4 and CD8 samples were reconstructed based on the corresponding number $(17,296)$ of randomly selected in silico TCR cDNA molecules (repertoires * F1, *CD4 and *CD8). After 100 independent rounds of analysis, about $30 \%$ of clonotypes in each repertoire were shown to overlap with the clonotypes in sample F2, representing $30 \%$ to $50 \%$ of the total number of analyzed T-cells from ${ }^{*} \mathrm{~F} 1,{ }^{*} \mathrm{CD} 4$ and ${ }^{*} \mathrm{CD} 8$ repertoires. For the $\mathrm{CD}^{+}{ }^{+} \mathrm{CD} 38^{+}+\mathrm{HLA}-\mathrm{DR}^{+}$subset these proportions were twice as low (Fig. 1). This fact indicates a considerable enrichment of the $\mathrm{CD}^{+}{ }^{+} \mathrm{CD} 38^{+}{ }^{+} \mathrm{HLA}-\mathrm{DR}^{+}$subset with $\mathrm{T}$-cell clones which have too low abundance in the total repertoire to be detected in the independent sample of the same volume.

Over 1,500 clonotypes in the repertoire of activated T-lymphocytes accounted for $13.1 \%$ of the clonal diversity and for $20 \%$ of the total number of analyzed T-cells, and were present in at least one of the two independent samples of unfractionated peripheral blood lymphocytes (F1 and F2). The depth of analysis was 2 million T-cells for the total T-cell repertoire. The proportion of peripheral blood T-cells represented by such clonotypes was $8.5 \%$. Of those clonotypes, only a few

Table 1. Comparison of $\mathrm{CD} 3+\mathrm{CD} 38^{+} \mathrm{HLA}-\mathrm{DR}^{+}$clonal composition with the total repertoire of peripheral blood T-cells

\begin{tabular}{|c|c|c|c|}
\hline Associated phenotype $^{*}$ & Found in both samples (F1 and F2)** & Found either in F1 or F2** $^{*}$ Absent in both samples $^{\star \star *}$ & $148(1,2 \%)$ \\
\hline CD4 & $505(4.2 \%)$ & $29(0,2 \%)$ & $119(1 \%)$ \\
\hline CD8 & $282(2.4 \%)$ & $425(3,6 \%)$ & $32(0.3 \%)$ \\
\hline Unknown & $175(1.5 \%)$ & $10212(85.6 \%)$ & \\
\hline
\end{tabular}

Note. * - association with the subset of cytotoxic of helper T-cells based on the analysis of CD8 ${ }^{+}$and CD4+ samples' repertoires; ** — percent of the total clonal diversity of the studied subset; ${ }^{* \star \star}$ — the number of clonotypes detected only in the $C D 3^{+} C D 38^{+} D R^{+}$subset. 
were relatively abundant in the total repertoire of the patient's T-cells (Fig. 2). Thus, of 100 most abundant clonotypes in total repertoire only 45 were discovered in the $\mathrm{CD}^{+}{ }^{+} \mathrm{CD} 38^{+} \mathrm{HLA}-\mathrm{DR}^{+}$ subset (39 and 6 clonotypes from cytotoxic and helper T-cell subsets, respectively).

The analysis of clonal overlap revealed that the majority of $\mathrm{CD}^{+}{ }^{+} \mathrm{CD} 38^{+} \mathrm{HLA}-\mathrm{DR}{ }^{+}$T-lymphocytes in terms of clonal diversity and clonal abundance were represented by the clones with low abundance in the total T-cell pool. Low abundance of $90 \%$ of clonotypes results in the inability to detect them in the samples of unfractionated peripheral T-cells at a standard depth of analysis (a few millions of separate peripheral blood T-cells).

\section{The structure of clonal repertoire of $\mathrm{CD}^{+}{ }^{+} \mathrm{CD} 38^{+} \mathrm{HLA}-\mathrm{DR}{ }^{+}$ T-lymphocytes}

Variable domain of TCR $\beta$ largely or fully determines the specificity of a T-lymphocyte clone to an antigen complexed with an $\mathrm{MHC}$ molecule (main histocompatibility complex, $\mathrm{MHC}$ [18-20]. In our study, for analysis of clonal repertoire of activated T-cells each clonotype was defined as a combination of an amino acid sequence of a hypervariable CDR3 region and a $\mathrm{V}$-segment identifier, which is a component of a mature TCR gene and determines the structure of the rest part of the betachain variable domain.

The clonal repertoire of activated T-cells from peripheral blood of the AS patient was relatively diverse; this diversity was comparable to that of the total T-cell repertoire. Analysis of the sequencing data demonstrated that majority of T-cells in the subpopulation has a unique variant of a TCR $\beta$ variable domain: we reconstructed as many as 12,000 different clonotypes from 17,000 TCR cDNA molecules. Note that for the samples F1 and $\mathrm{F} 2$ representing the total $\mathrm{T}$-cell population, we identified about 550,000 unique clonotypes from 1 million sequences of TCR cDNA molecules.

The distribution of clonal abundance of $\mathrm{CD}^{+} \mathrm{CD} 38^{+} \mathrm{HLA}$ $\mathrm{DR}^{+}$fraction was the same as in the total T-cell repertoire (sample F1). The most abundant clonotype in the fraction accounted for $0.27 \%$ of the total T-cell population. Note that the most abundant clonotype in the total T-cell repertoire (sample F1) accounted for $1.6 \%$ of all T-cells in the population. Top 100 most abundant clonotypes of activated T-cells or total repertoire accounted for $5.6 \%$ of the $\mathrm{CD}^{+}{ }^{+} \mathrm{CD} 38^{+} \mathrm{HLA}-\mathrm{DR}{ }^{+}$ subset or $9 \%$ of the total repertoire, respectively. No significant differences were observed between the sample $\mathrm{F} 1$ and the $\mathrm{CD}^{+} \mathrm{CD} 38^{+} \mathrm{HLA}-\mathrm{DR}^{+}$subset in terms of the abundance of clonotypes having a specific $\mathrm{V}$-segment in their TCR $\beta$ gene (those are clonotypes that presumably recognize peptides in complex with same MHC molecule). Compared to the total T-cell repertoire, there was a lack of enrichment of the activated T-cell population in clonotypes with a specific structure of a variable TCR $\beta$ region

\section{A search for AS-associated clonotypes}

T-cells expressing activation markers are directly involved in the immune response. This encourages us to hypothesize that the repertoire of activated T-cell subpopulations might be enriched with clonotypes associated with inflammation in patients with active spondylitis. To profile the $\mathrm{CD}^{+}{ }^{+} \mathrm{CD} 38^{+} \mathrm{HLA}-\mathrm{DR}{ }^{+}$subset, we performed a search for the AS-associated clonotypes that had been previously discovered in the peripheral blood and synovial fluid of $H L A-B^{\star} 27$ positive AS patients [3, 4]. The search list included clonotypes observed in the synovial fluid of at least two of three $H L A-B^{\star} 27$ positive patients whose repertoires had been characterized in our previous work [4]. This was necessary to minimize accidental and irrelevant clonotype matches between the repertoires of two donors and to focus on similar clonotypes found in inflamed joints of different individuals. The search list included 1,913 clonotypes: 11 CDR3 sequences constituting a motif associated with AS (as reported by the two studies mentioned above) and 1,902 clonotypes found in the synovial fluid of patients with AS.

We found 32 identical amino acid sequence of a TCR $\beta$ variable domain between 11,927 clonotypes coming from the subset of activated T-lymphocytes and the clonotypes from our list. The majority of shared clonotypes had low abundance in the $\mathrm{CD}^{+}{ }^{+} \mathrm{CD} 38^{+} \mathrm{HLA}-\mathrm{DR}^{+}$T-cell subset (Fig. 3).

Eight of these 32 clonotypes were not found in the T-cell repertoires of peripheral blood samples from $H L A-B^{\star} 27$ positive healthy donors (data from [4]) (Table 2), suggesting the lack of expansion of these clonotypes in healthy individuals $[4,21,22]$. One of those 8 clonotypes, TRBV9_CASSVGVYSTDTQYF_ TRBJ2-3, belongs to the group of 11 variations of the variable TCR sequence that constitute the CDR3 motif associated with AS. The motif was also previously found in the synovial fluid of $H L A-B^{*} 27$ positive patients with reactive arthritis [5, 23]. In our study this clonotype was associated with the CD8+ T-cell subset just like in three previously published works reporting its presence in the samples of patients with spondyloarthropathies (AS and reactive arthritis).

For two months after the first sampling the disease status of the patient remained unchanged, and we profiled the repertoire of his activated T-cell clones once again (time point 2). Using flow cytometry, we obtained $16,000 \mathrm{CD}^{+} \mathrm{CD} 8^{+} \mathrm{CD} 38^{+} \mathrm{HLA}$ $\mathrm{DR}^{+}$and $10,500 \mathrm{CD}^{+}{ }^{+} \mathrm{CD} 8-\mathrm{CD} 38+\mathrm{HLA}-\mathrm{DR}^{+}$lymphocytes and reconstructed 3,900 and 8,300 TCR $\beta$ clonotypes, respectively. The depth of analysis was comparable to that performed two months before in terms of quantity of the identified clonotypes. The subpopulations of the activated T-cell clones isolated at time points 1 and 2 shared $3 \%$ of clonotypes coming from the cytotoxic and helper subsets in equal proportions: of 323 clonotypes of activated T-cells covered by the analysis at both time points, 154 were associated with the CD8 ${ }^{+}$phenotype, 136 - with the CD4+ phenotype; the remaining 33 clonotypes

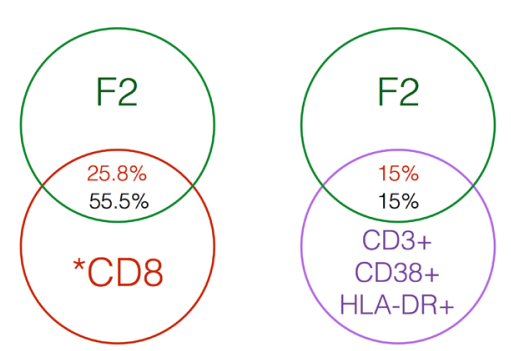

Fig. 1. Comparison of clonal composition of different T-cell subpopulations. Percent of the clonal diversity (shown in red) and percent of the T-cell repertoire (shown in black) represented by clonotypes shared by two compared samples. *F1, *CD4, *CD8 are repertoires of F1, CD4, and CD8 samples, respectively, reconstructed on the basis of 17, 523 randomly in silico selected TCR cDNA molecules (that equals to the number of TCR cDNA molecules covered by the analysis of the CD3+CD38+HLA$\mathrm{DR}^{+}$subset) 
were not attributed to any phenotype during the analysis at time point 1.

In repertoire of $\mathrm{CD}^{+}$activated T-lymphocytes in time point 2, we also found the clonotype TRBV9_CASSVGVYSTDTQYF_ TRBJ2-3 along with the three other clonotypes that had been previously discovered in the synovial fluid of patients with AS but not in the peripheral blood of healthy $H L A-B^{\star} 27$ positive donors (Table 2). The amino acid sequence of the variable TCR $\beta$ region of another clonotype discovered at time point 2 was highly homologous to the published clonotypes associated with AS due to the identical $V$-segment in the TCR gene sequence and a similar sequence of a hypervariable CDR3 region. This clonotype was observed in the repertoire of peripheral blood lymphocytes in $40 \%$ of patients with AS ( $n=25)$ [4] and in two of the three studied T- cell repertoires of the synovial fluid; it was, however, absent in all blood samples of $H L A-B^{*} 27$ positive donors $(n=7)$ (Table 2 ).

\section{DISCUSSION}

Surface molecules CD38 and HLA-DR are markers that discriminate activated T-cells, a subpopulation of T-lymphocytes exerting their effector function during the immune response, such as the response to viral invasion [24-27]. Increased frequency of T-cells with the CD38+HLA-DR+ ${ }^{+}$phenotype was shown in the peripheral blood of patients with autoimmune inflammatory bowel diseases that often accompany spondyloarthropathies and ankylosing spondylitis, in particular [28]. According to the recent study of anti-cytokine treatment effectiveness, unlike healthy donors, patients with AS have higher frequency of cytotoxic HLA-DR+ ${ }^{+}$T-cells in their peripheral blood; the study also demonstrates that the frequency of HLA$\mathrm{DR}^{+}$helper T-cells differ significantly between patients who respond to treatment and those who do not [29]. Discovery

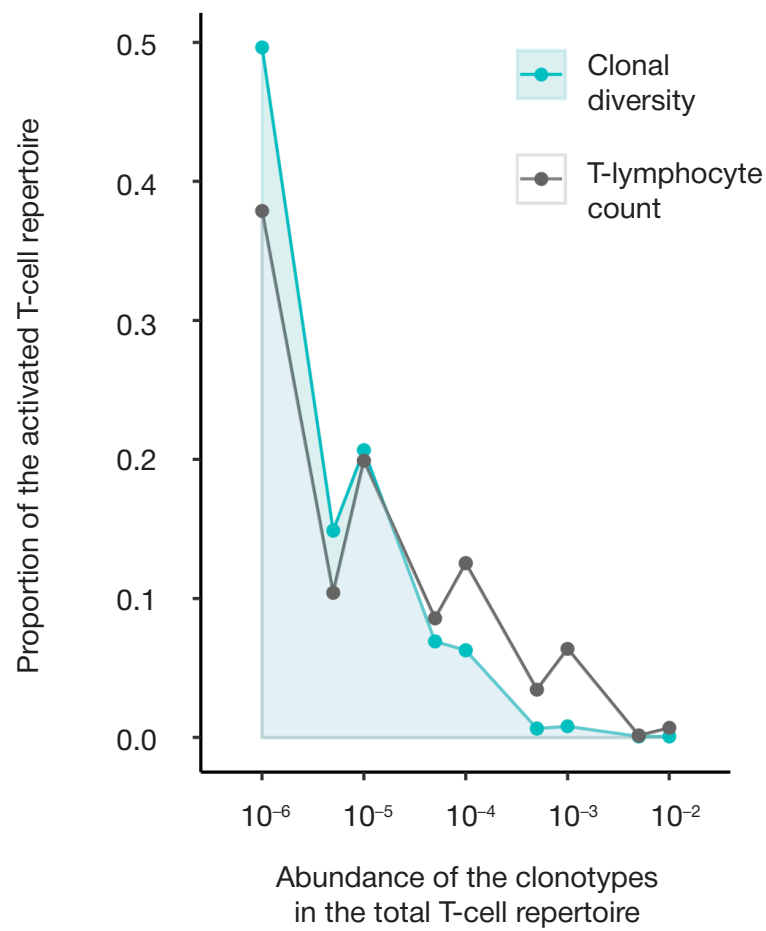

Fig. 2. Distribution of the clonotypes identified in the $C D 3^{+} \mathrm{CD} 38^{+} \mathrm{HLA}-\mathrm{DR}{ }^{+}$subset depending on their abundance in the total repertoire (F1). The $Y$ axis represents the proportion of clonotypes in the studied subset relative to the total number of clonotypes in the subset; the $\mathrm{X}$ axis represents the abundance of clonotypes in the total repertoire of T-cells of AS-associated T-cell clones with a highly homologous TCR structure $[3,4]$ encourages research of clonal composition of functionally different T-cell subsets in patients with AS that could elucidate the role of T-cells in the disease. In our study we used a state-of-the-art technique for cDNA library preparation and sequencing data analysis, and pioneered the exploration of the structure and clonal composition of the repertoire of activated peripheral blood T-cells from patients with AS. Low probability of clonal composition bias and quantitative assessment of the abundance of each clonotype in a sample were important features of the TCR repertoire profiling technology used for the present study.

The analysis of clonotype abundance in the activated T-cell subset and the total T-cell repertoire has revealed a unique composition of the activated T-cell subpopulation: it is enriched in clonotypes that cannot be detected in unfractionated blood samples or in the subpopulations of $\mathrm{CD}^{+}-$and $\mathrm{CD}^{+}$ T-lymphocytes owing to their low abundance. A low degree of overlap between the repertoires of activated T-cells obtained at two different time points is probably the result of low abundance of these clonotypes in peripheral blood.

The fact that the majority of clonotypes found in activated T-cell subset had low abundance could be explained by the enrichment of the fraction with clones participating in inflammation and normally localized at inflammation sites. Komech et al. [4] report higher abundance in synovial fluid compared to peripheral blood of patients with acute synovitis for AS-associated clonotypes. However, at the given depth of analysis achieved in our study, clonal diversity of the activated T-cell subpopulation almost mirrors that of the total T-cell repertoire in peripheral blood. We have not observed prominent clonal expansions or enrichment in clonotypes with a specific structure of a variable TCR $\beta$ domain in the activated T-cell subset. Using a recently created database of clonotypes with well-characterized specificity to different $\mathrm{MHC} /$ peptide

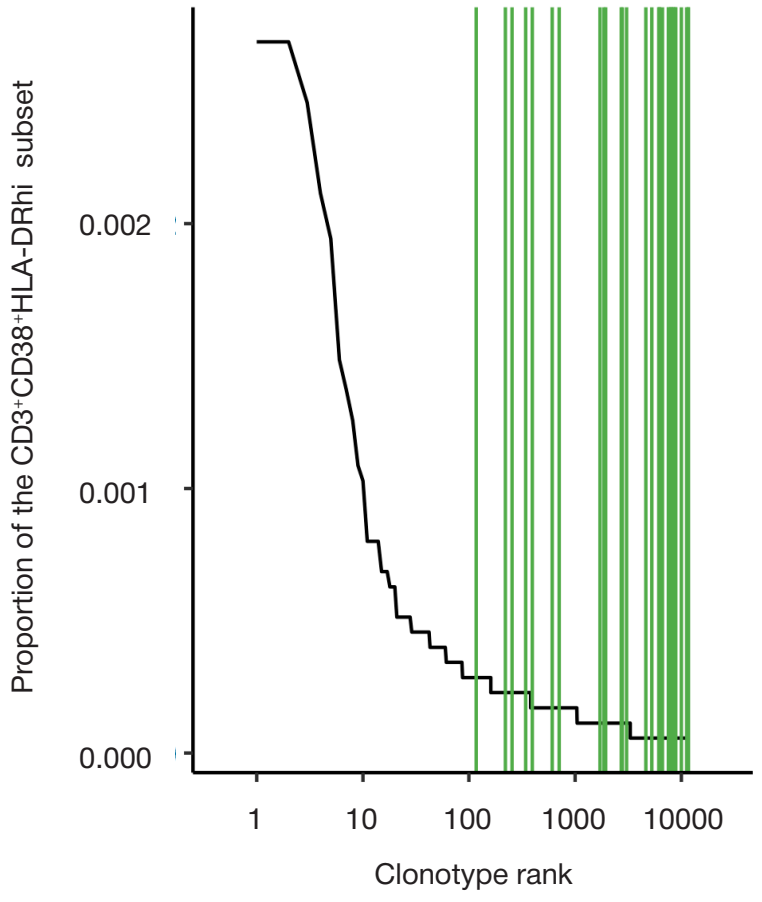

Fig. 3. Abundance of the clonotypes associated with AS and found in the synovial fluid of patients with AS in the repertoire of activated T-cells. Rank (reference number) in the repertoire of activated T-cells for each clonotype from the list (see explanation in the text), is represented by green vertical line 
Table 2. Analysis of frequency in the peripheral blood and synovial fluid samples of patients with AS for the clonotypes identified in CD $3^{+} \mathrm{CD} 38^{+}+\mathrm{HLA}-\mathrm{DR}{ }^{+}$subset

\begin{tabular}{|c|c|c|c|c|c|}
\hline Amino acid sequence & V-segment & $\begin{array}{c}\text { Frequency in the samples } \\
\text { obtained from patients } \\
\text { with } \mathrm{AS}^{\star \star}(\mathrm{n}=25), \%\end{array}$ & $\begin{array}{c}\text { Number of synovial fluid } \\
\text { samples }(n=3)\end{array}$ & $\begin{array}{l}\text { Associated } \\
\text { phenotype }\end{array}$ & Sample \\
\hline CASSLGPGSYEQYF & TRBV5-1 & $32.0(8)$ & 3 & $\mathrm{CD} 4$ & Time point 1 \\
\hline CASSVGVYSTDTQYF & TRBV9 & $24.0(6)$ & 1 & CD8 & Time points 1 and $2\left(\mathrm{CD} 8^{+}\right)$ \\
\hline CASSSRGPYEQYF & TRBV7-2 & $16.0(4)$ & 2 & - & Time point 1 \\
\hline CASSDYNEQFF & TRBV2 & $16.0(4)$ & 2 & $\mathrm{CD} 4$ & Time point 1 \\
\hline CASSQEGQESDTQYF & TRBV4-2 & $12.0(3)$ & 2 & - & Time point 1 \\
\hline CASSLGGRNNEQFF & TRBV5-1 & 4.0 (1) & 2 & - & Time point 1 \\
\hline CAWSLGVNQPQHF & TRBV30 & 4.0 (1) & 2 & - & Time point 1 \\
\hline CASSYSGGSGYTF & TRBV6-5 & $0(0)$ & 2 & $\mathrm{CD} 4$ & Time point 1 \\
\hline CASSVGGDYGYTF & TRBV9 & $40.0(10)$ & 2 & $\mathrm{CD} 8$ & Time point $2\left(\mathrm{CD} 8^{+}\right)$ \\
\hline CASSLGLSGANVLTF & TRBV5-6 & $8.0(2)$ & 2 & - & Time point $2\left(\mathrm{CD} 8^{+}\right)$ \\
\hline CASSQAGAYQETQYF & TRBV4-2 & $0(0)$ & 2 & - & Time point $2\left(\mathrm{CD}^{-}\right)$ \\
\hline
\end{tabular}

Note. * - The list includes clonotypes of the $\mathrm{CD} 3^{+} \mathrm{CD} 38^{+} \mathrm{HLA}-\mathrm{DR}{ }^{+}$cell subset isolated from the peripheral blood of the patient that were not found in the repertoires of healthy HLA-B*27 positive donors; ${ }^{* *}$ — the number of peripheral blood samples of AS patients, where the clonotype was identified, is specified in brackets; ${ }_{* * \star}$ - association with the subset of cytotoxic of helper T-cells based on the analysis of the repertoire of CD8 ${ }^{+}$and CD4 ${ }^{+}$samples.

complexes [30], we have found a few matches of a TCR $\beta$ amino acid sequence between clonotypes in the repertoire of activated T-cell subset and clonotypes in the database, which are specific to some immunogenic of influenza virus, CMV and EBV. This suggests that T-lymphocytes found in the patient's peripheral blood expressing HLA-DR and CD38 activation markers represent a subset of T-cells that actively participate in the immune response against a broad range of antigens.

To search for the clonotypes associated with AS we used T-cell repertoire data for the peripheral blood and synovial fluid samples of healthy $H L A-B^{*} 27$-positive donors obtained earlier using with the same technology for T-cell repertoire reconstruction. After analysis of two repertoires of activated T-cells obtained at different time points using different flow cytometry gating strategies, we found 11 clonotypes that were absent in the repertoires of healthy donors but observed in the synovial fluid of at least two patients with AS. None of those 11 clonotypes was found in the repertoires of patients' peripheral blood. The presence of these clonotypes in the repertoires of $H L A-B^{*} 27$ positive patients with $A S$ and their absence in healthy $H L A-B^{\star} 27$ positive patients demonstrates their ability to undergo selection in the thymus in the presence of $\mathrm{HLA}-\mathrm{B}^{\star} 27$, followed by the clonal expansion in patients but not in healthy $H L A-B^{\star} 27$ positive individuals [21].

Among the aforementioned 11 sequences of the variable TCR $\beta$ domain there was the TRBV9_CASSVGVYSTDTQYF_ TRBJ2-3 clonotype previously associated with AS based on the recent studies of the T-cell clonal repertoire of the peripheral blood [3] and synovial fluid [4] of patients with AS. An identical clonotype was previously discovered in the synovial fluid of $H L A-B^{\star} 27$ positive patients with reactive arthritis [5, 23]. This clonotype was associated with the subpopulation of cytotoxic T-lymphocytes in the mentioned research works and in our present study as well. Upon analyzing the clonal repertoire of two independent samples of activated T-cells isolated from the peripheral blood using different gating strategies at two different time points, we managed to prove the long-term presence of this clonotype in the activated T-cell subpopulation of peripheral blood of the patient.
The activated cytotoxic T-cell subset contained the clonotype TRBV9_CASSVGGDYGYTF_TRBJ1-2 found in the peripheral blood samples of $40 \%$ of AS patients $(n=25)$ and in two of three samples of synovial fluid from patients. A high frequency of this clonotype in the synovial fluid and peripheral blood of patients with AS, a certain degree of homology of its variable TCR $\beta$ domain to other clonotypes previously discovered in patients with reactive arthritis and AS and its absence in the peripheral blood of healthy $H L A-B^{\star} 27$ positive donors allow to suggest a possible role of this clonotype in inflammation in ankylosing spondylitis. Besides, some clonotypes from the helper subpopulation might also be linked to $\mathrm{AS}$, given the presence of a few $\mathrm{CD}^{+}$clonotypes in the repertoire of the activated T-cells that share the same structure of the variable TCR $\beta$ domain with the clonotypes of the CD4 ${ }^{+}$ T-cell subset isolated from the synovial fluid of patients with $\mathrm{AS}$ and considering the absence of these $\mathrm{CD} 4^{+}$clonotypes the peripheral blood of healthy $H L A-B^{\star} 27$ positive donors.

\section{CONCLUSIONS}

We have performed for the first time a study of clonal repertoire of a T-cell subset expressing activation markers HLA-DR and CD38 from the peripheral blood of a patient with active ankylosing spondylitis. Clonal repertoire of the subpopulation was not highly oligoclonal and was enriched in clonotypes poorly represented in the total T-cell repertoire. We have discovered a number of clonotypes of cytotoxic and helper T-cells possibly implicated in inflammation process in AS. Most importantly, in the subpopulation of cytotoxic activated T-cells we have identified a clonotype, which was previously associated with AS in other recent studies. Expression of activation markers by T-cells of the AS-associated clones suggests their active role in inflammation. Further research is necessary to investigate the clonal repertoire of functionally different T-cell populations and to determine antigen specificity of the identified clonotypes, which will facilitate our understanding of mechanisms underlying AS initiation and development and help to design specific treatment strategies for the disease. 
1. Brown MA, Kenna T, Wordsworth BP. Genetics of ankylosing spondylitis - insights into pathogenesis. Nat Rev Rheumatol. 2016 Feb; 12 (2): 81-91. DOI: 10.1038/nrrheum.2015.133.

2. Benjamin R, Parham P. Guilt by association: HLA-B27 and ankylosing spondylitis. Immunol Today. 1990 Apr; 11 (4): 137-42.

3. Faham M, Carlton V, Moorhead M, Zheng J, Klinger M, Pepin F et al. Discovery of T-Cell Receptor Beta Motifs Specific to HLA-B27(+) Ankylosing Spondylitis by Deep Repertoire Sequence Analysis. Arthritis Rheumatol. 2017 Apr; 69 (4): 774-84. DOI: 10.1002/art.40028.

4. Komech EA, Pogorelyy MV, Egorov ES, Britanova OV, Rebrikov DV, Bochkova AG et al. CD8+ T cells with characteristic TCR beta motif are detected in blood and expanded in synovial fluid of ankylosing spondylitis patients. Rheumatology (Oxford). Forthcoming 2018.

5. Duchmann R, May E, Ackermann B, Goergen B, Meyer zum Büschenfelde KH, Märker-Hermann E. HLA-B27-restricted cytotoxic T lymphocyte responses to arthritogenic enterobacteria or self-antigens are dominated by closely related TCRBV gene segments. A study in patients with reactive arthritis. Scand $J$ Immunol. 1996 Jan; 43 (1): 101-8.

6. Dulphy N, Peyrat MA, Tieng V, Douay C, Rabian C, Tamouza R et al. Common intra-articular $T$ cell expansions in patients with reactive arthritis: identical beta-chain junctional sequences and cytotoxicity toward HLA-B27. J Immunol. 1999 Apr 1; 162 (7): 3830-9.

7. May E, Dulphy N, Frauendorf E, Duchmann R, Bowness P, Lopez de Castro JA et al. Conserved TCR beta chain usage in reactive arthritis; evidence for selection by a putative HLA-B27associated autoantigen. Tissue Antigens. 2002 Oct; 60 (4): 299308.

8. Kivioja $\mathrm{T}$, Vähärautio $\mathrm{A}$, Karlsson $\mathrm{K}$, Bonke $\mathrm{M}$, Enge $\mathrm{M}$, Linnarsson $S$ et al. Counting absolute numbers of molecules using unique molecular identifiers. Nat Methods. 2011 Nov 20; 9 (1): 72-4. DOI: 10.1038/nmeth.1778.

9. Mamedov IZ, Britanova OV, Zvyagin IV, Turchaninova MA, Bolotin DA, Putintseva EV et al. Preparing unbiased T-cell receptor and antibody cDNA libraries for the deep next generation sequencing profiling. Front Immunol. 2013; 4: 456. Published online 2013 Dec 23. DOI: 10.3389/fimmu.2013.00456.

10. Zvyagin IV, Mamedov IZ, Tatarinova OV, Komech EA, Kurnikova EE, Boyakova EV et al. Tracking T-cell immune reconstitution after TCR $\alpha \beta / C D 19$-depleted hematopoietic cells transplantation in children. Leukemia. 2017; (31): 1145-53. DOI: 10.1038/leu.2016.321.

11. Shugay M, Britanova OV, Merzlyak EM, Turchaninova MA, Mamedov IZ, Tuganbaev TR et al. Towards error-free profiling of immune repertoires. Nat Methods. 2014 Jun; 11 (6): 653-5. DOI: 10.1038/nmeth.2960. Epub 2014 May 4.

12. Bolotin DA, Poslavsky S, Mitrophanov I, Shugay M, Mamedov IZ, Putintseva EV et al. MiXCR: software for comprehensive adaptive immunity profiling. Nat Methods. 2015 May; 12 (5): 380-1. DOI: 10.1038/nmeth.3364.

13. Britanova OV, Putintseva EV, Shugay M, Merzlyak EM, Turchaninova MA, Staroverov DB et al. Age-related decrease in TCR repertoire diversity measured with deep and normalized sequence profiling. J Immunol. 2014 Mar 15; 192 (6): 2689-98. DOI: $10.4049 / \mathrm{jimm}$ unol.1302064.

14. R Core Team. R: A language and environment for statistical computing. R Foundation for Statistical Computing. Vienna, Austria. 2014. Available from: http://www.r-project.org/.

15. Bisset LR, Lung TL, Kaelin M, Ludwig E, Dubs RW. Reference values for peripheral blood lymphocyte phenotypes applicable to the healthy adult population in Switzerland. Eur J Haematol. 2004 Mar; 72 (3): 203-12. DOI: 10.1046/j.0902-4441.2003.00199.x.

16. Egorov ES, Merzlyak EM, Shelenkov AA, Britanova OV, Sharonov GV, Staroverov DB et al. Quantitative Profiling of
Immune Repertoires for Minor Lymphocyte Counts Using Unique Molecular Identifiers. J Immunol. 2015 Jun 15; 194 (12): 6155-63. DOI: 10.1049/jimmunol.1500215.

17. Qi Q, Liu Y, Cheng Y, Glanville J, Zhang D, Lee JY et al. Diversity and clonal selection in the human T-cell repertoire. Proc Natl Acad Sci U S A. 2014 Sep 9; 111 (36): 13139-44. DOI: 10.1073/ pnas.1409155111.

18. Koning D, Costa Al, Hoof I, Miles JJ, Nanlohy NM, Ladell K et al. CD8+ TCR repertoire formation is guided primarily by the peptide component of the antigenic complex. J Immunol. 2013 Feb 1; 190 (3): 931-9. DOI: 10.4049/jimmunol.1202466.

19. Birnbaum ME, Mendoza JL, Sethi DK, Dong S, Glanville J, Dobbins $\mathrm{J}$ et al. Deconstructing the Peptide-MHC Specificity of T Cell Recognition. Cell. 2014 May 22; 157 (5): 1073-87. DOI: 10.1016/j.cell.2014.03.047.

20. Zvyagin IV, Pogorelyy MV, Ivanova ME, Komech EA, Shugay M, Bolotin DA et al. Distinctive properties of identical twins' TCR repertoires revealed by high-throughput sequencing. Proc Natl Acad Sci U S A. 2014 Apr 22; 111 (16): 5980-5. DOI: 10.1073/ pnas.1319389111.

21. Elhanati $Y$, Murugan A, Callan CG, Mora T, Walczak AM. Quantifying selection in immune receptor repertoires. Proc Natl Acad Sci U S A. 2014 Jul 8; 111 (27): 9875-80. DOI: 10.1073/ pnas.1409572111.

22. Pogorelyy MV, Minervina AA, Chudakov DM, Mamedov IZ, Lebedev YB, Mora T et al. Method for identification of conditionassociated public antigen receptor sequences. BioRxiv 195057. DOI: 10.1101/195057.

23. Dulphy N, Peyrat MA, Tieng V, Douay C, Rabian C, Tamouza R et al. Common intra-articular $\mathrm{T}$ cell expansions in patients with reactive arthritis: identical beta-chain junctional sequences and cytotoxicity toward HLA-B27. J Immunol. 1999 Apr 1; 162 (7): 3830-39.

24. Akondy RS, Monson ND, Miller JD, Edupuganti S, Teuwen D, $\mathrm{Wu} \mathrm{H}$ et al. The yellow fever virus vaccine induces a broad and polyfunctional human memory CD8+ T cell response. J Immunol. 2009 Dec 15; 183 (12): 7919-30. DOI: 10.4049/ jimmunol.08039003.

25. Meditz AL, Haas MK, Folkvord JM, Melander K, Young R, McCarter M et al. HLA-DR+ CD38+ CD4+ T Lymphocytes Have Elevated CCR5 Expression and Produce the Majority of R5-Tropic HIV-1 RNA In Vivo. J Virol. 2011 Oct; 85 (19): 10189-200. DOI: 10.1128/JVI.02529-10. Epub 2011 Aug 3.

26. Blom K, Braun M, Ivarsson MA, Gonzalez VD, Falconer K, Moll M et al. Temporal dynamics of the primary human $T$ cell response to yellow fever virus $17 \mathrm{D}$ as it matures from an effector- to a memory-type response. J Immunol. 2013 Mar 1; 190 (5): 2150-8. DOI: 10.4049/jimmunol.1202234.

27. Blom K, Braun M, Pakalniene J, Dailidyte L, Béziat V, Lampen MH et al. Specificity and dynamics of effector and memory CD8 T cell responses in human tick-borne encephalitis virus infection. PLOS Pathog. 2015 Jan 22; 11 (1): e1004622. DOI: 10.1371/journal. ppat.1004622.

28. Funderburg NT, Stubblefield Park SR, Sung HC, Hardy G, Clagett $\mathrm{B}$, Ignatz-Hoover $\mathrm{J}$ et al. Circulating CD4(+) and CD8(+) $\mathrm{T}$ cells are activated in inflammatory bowel disease and are associated with plasma markers of inflammation. Immunology. 2013 Sep; 140 (1): 87-97. DOI: 10.1111/imm.12114.

29. Dulic S, Vasarhelyi Z, Bajnok A, Szalay B, Toldi G, Kovacs $L$ et al. The Impact of Anti-TNF Therapy on CD4+ and CD8+ Cell Subsets in Ankylosing Spondylitis. Pathobiology. 2017 Dec 6. DOI: 10.1159/000484250. [Epub ahead of print.]

30. Shugay M, Bagaev DV, Zvyagin IV, Vroomans RM, Crawford JC, Dolton $G$ et al. VDJdb: a curated database of T-cell receptor sequences with known antigen specificity. Nucleic Acids Res. 2018 Jan 4; 46 (D1): D419-D427. DOI: 10.1093/nar/gkx760. 


\section{Литература}

1. Brown MA, Kenna T, Wordsworth BP. Genetics of ankylosing spondylitis - insights into pathogenesis. Nat Rev Rheumatol. 2016 Feb; 12 (2): 81-91. DOI: 10.1038/nrrheum.2015.133.

2. Benjamin R, Parham P. Guilt by association: HLA-B27 and ankylosing spondylitis. Immunol Today. 1990 Apr; 11 (4): 137-42.

3. Faham M, Carlton V, Moorhead M, Zheng J, Klinger M, Pepin F et al. Discovery of T-Cell Receptor Beta Motifs Specific to HLA-B27(+) Ankylosing Spondylitis by Deep Repertoire Sequence Analysis. Arthritis Rheumatol. 2017 Apr; 69 (4): 774-84. DOl: 10.1002/art.40028.

4. Komech EA, Pogorelyy MV, Egorov ES, Britanova OV, Rebrikov DV, Bochkova AG et al. CD8+ T cells with characteristic TCR beta motif are detected in blood and expanded in synovial fluid of ankylosing spondylitis patients. Rheumatology (Oxford). Forthcoming 2018 .

5. Duchmann R, May E, Ackermann B, Goergen B, Meyer zum Büschenfelde KH, Märker-Hermann E. HLA-B27-restricted cytotoxic T lymphocyte responses to arthritogenic enterobacteria or self-antigens are dominated by closely related TCRBV gene segments. A study in patients with reactive arthritis. Scand J Immunol. 1996 Jan; 43 (1): 101-8.

6. Dulphy N, Peyrat MA, Tieng V, Douay C, Rabian C, Tamouza R et al. Common intra-articular $\mathrm{T}$ cell expansions in patients with reactive arthritis: identical beta-chain junctional sequences and cytotoxicity toward HLA-B27. J Immunol. 1999 Apr 1; 162 (7): 3830-9.

7. May E, Dulphy N, Frauendorf E, Duchmann R, Bowness $P$, Lopez de Castro JA et al. Conserved TCR beta chain usage in reactive arthritis; evidence for selection by a putative HLA-B27associated autoantigen. Tissue Antigens. 2002 Oct; 60 (4): 299308.

8. Kivioja $\mathrm{T}$, Vähärautio $\mathrm{A}$, Karlsson $\mathrm{K}$, Bonke $\mathrm{M}$, Enge $\mathrm{M}$, Linnarsson $S$ et al. Counting absolute numbers of molecules using unique molecular identifiers. Nat Methods. 2011 Nov 20; 9 (1): 72-4. DOI: 10.1038/nmeth.1778.

9. Mamedov IZ, Britanova OV, Zvyagin IV, Turchaninova MA, Bolotin DA, Putintseva EV et al. Preparing unbiased T-cell receptor and antibody cDNA libraries for the deep next generation sequencing profiling. Front Immunol. 2013; 4: 456. Published online 2013 Dec 23. DOI: 10.3389/fimmu.2013.00456.

10. Zvyagin IV, Mamedov IZ, Tatarinova OV, Komech EA, Kurnikova EE, Boyakova EV et al. Tracking T-cell immune reconstitution after TCR $\alpha \beta / C D 19$-depleted hematopoietic cells transplantation in children. Leukemia. 2017; (31): 1145-53. DOI: 10.1038/leu.2016.321

11. Shugay M, Britanova OV, Merzlyak EM, Turchaninova MA Mamedov IZ, Tuganbaev TR et al. Towards error-free profiling of immune repertoires. Nat Methods. 2014 Jun; 11 (6): 653-5. DOl: 10.1038/nmeth.2960. Epub 2014 May 4.

12. Bolotin DA, Poslavsky S, Mitrophanov I, Shugay M, Mamedov IZ, Putintseva EV et al. MiXCR: software for comprehensive adaptive immunity profiling. Nat Methods. 2015 May; 12 (5): 380-1. DOI: 10.1038/nmeth.3364

13. Britanova OV, Putintseva EV, Shugay M, Merzlyak EM, Turchaninova MA, Staroverov DB et al. Age-related decrease in TCR repertoire diversity measured with deep and normalized sequence profiling. J Immunol. 2014 Mar 15; 192 (6): 2689-98. DOI: 10.4049/jimmunol.1302064.

14. R Core Team. R: A language and environment for statistical computing. R Foundation for Statistical Computing. Vienna, Austria. 2014. Available from: http://www.r-project.org/.

15. Bisset LR, Lung TL, Kaelin M, Ludwig E, Dubs RW. Reference values for peripheral blood lymphocyte phenotypes applicable to the healthy adult population in Switzerland. Eur J Haematol. 2004 Mar; 72 (3): 203-12. DOI: 10.1046/j.0902-4441.2003.00199.x.

16. Egorov ES, Merzlyak EM, Shelenkov AA, Britanova OV, Sharonov GV, Staroverov DB et al. Quantitative Profiling of
Immune Repertoires for Minor Lymphocyte Counts Using Unique Molecular Identifiers. J Immunol. 2015 Jun 15; 194 (12): 6155-63. DOI: 10.1049/jimmunol.1500215.

17. Qi Q, Liu Y, Cheng Y, Glanville J, Zhang D, Lee JY et al. Diversity and clonal selection in the human T-cell repertoire. Proc Natl Acad Sci U S A. 2014 Sep 9; 111 (36): 13139-44. DOI: 10.1073/ pnas. 1409155111

18. Koning D, Costa Al, Hoof I, Miles JJ, Nanlohy NM, Ladell K et al. CD8+ TCR repertoire formation is guided primarily by the peptide component of the antigenic complex. J Immunol. 2013 Feb 1; 190 (3): 931-9. DOI: 10.4049/jimmunol.1202466.

19. Birnbaum ME, Mendoza JL, Sethi DK, Dong S, Glanville J, Dobbins $J$ et al. Deconstructing the Peptide-MHC Specificity of T Cell Recognition. Cell. 2014 May 22; 157 (5): 1073-87. DOI: 10.1016/j.cell.2014.03.047.

20. Zvyagin IV, Pogorelyy MV, Ivanova ME, Komech EA, Shugay M, Bolotin DA et al. Distinctive properties of identical twins' TCR repertoires revealed by high-throughput sequencing. Proc Natl Acad Sci U S A. 2014 Apr 22; 111 (16): 5980-5. DOI: 10.1073/ pnas.1319389111.

21. Elhanati $Y$, Murugan A, Callan CG, Mora T, Walczak AM. Quantifying selection in immune receptor repertoires. Proc Natl Acad Sci U S A. 2014 Jul 8; 111 (27): 9875-80. DOI: 10.1073/ pnas.1409572111.

22. Pogorelyy MV, Minervina AA, Chudakov DM, Mamedov IZ, Lebedev YB, Mora T et al. Method for identification of conditionassociated public antigen receptor sequences. BioRxiv 195057. DOI: 10.1101/195057.

23. Dulphy N, Peyrat MA, Tieng V, Douay C, Rabian C, Tamouza R et al. Common intra-articular $T$ cell expansions in patients with reactive arthritis: identical beta-chain junctional sequences and cytotoxicity toward HLA-B27. J Immunol. 1999 Apr 1; 162 (7): 3830-39.

24. Akondy RS, Monson ND, Miller JD, Edupuganti S, Teuwen D, $\mathrm{Wu} \mathrm{H}$ et al. The yellow fever virus vaccine induces a broad and polyfunctional human memory CD8+ T cell response. J Immunol. 2009 Dec 15; 183 (12): 7919-30. DOI: 10.4049/ jimmunol.08039003.

25. Meditz AL, Haas MK, Folkvord JM, Melander K, Young R, McCarter M et al. HLA-DR+ CD38+ CD4+ T Lymphocytes Have Elevated CCR5 Expression and Produce the Majority of R5-Tropic HIV-1 RNA In Vivo. J Virol. 2011 Oct; 85 (19): 10189-200. DOI: 10.1128/JVI.02529-10. Epub 2011 Aug 3.

26. Blom K, Braun M, Ivarsson MA, Gonzalez VD, Falconer K, Moll M et al. Temporal dynamics of the primary human $T$ cell response to yellow fever virus 17D as it matures from an effector- to a memory-type response. J Immunol. 2013 Mar 1; 190 (5): 2150-8. DOI: 10.4049/jimmunol.1202234.

27. Blom K, Braun M, Pakalniene J, Dailidyte L, Béziat V, Lampen MH et al. Specificity and dynamics of effector and memory CD8 T cell responses in human tick-borne encephalitis virus infection. PLoS Pathog. 2015 Jan 22; 11 (1): e1004622. DOI: 10.1371/journal. ppat.1004622.

28. Funderburg NT, Stubblefield Park SR, Sung HC, Hardy G, Clagett B, Ignatz-Hoover $\mathrm{J}$ et al. Circulating CD4(+) and CD8(+) $\mathrm{T}$ cells are activated in inflammatory bowel disease and are associated with plasma markers of inflammation. Immunology. 2013 Sep; 140 (1): 87-97. DOI: 10.1111/imm.12114.

29. Dulic S, Vasarhelyi Z, Bajnok A, Szalay B, Toldi G, Kovacs L et al. The Impact of Anti-TNF Therapy on CD4+ and CD8+ Cell Subsets in Ankylosing Spondylitis. Pathobiology. 2017 Dec 6. DOI: 10.1159/000484250. [Epub ahead of print.]

30. Shugay M, Bagaev DV, Zvyagin IV, Vroomans RM, Crawford JC, Dolton $G$ et al. VDJdb: a curated database of T-cell receptor sequences with known antigen specificity. Nucleic Acids Res. 2018 Jan 4; 46 (D1): D419-D427. DOI: 10.1093/nar/gkx760. 